\title{
Analisis Praanggapan pada Channel Youtobe Podcast Deddy Corbuzier Bersama Novel Baswedan
}

\section{Dira Elfitri ${ }^{1}$ \\ Fatmawati $^{2}$}

\author{
12Universitas Islam Riau
}

Diraelfitri12@gmail.com

\begin{abstract}
Abstrak
Praanggapan memiliki peran penting dalam berlangsungnya proses komunikasi, karena suatu komunikasi dapat terjalin dengan baik jika penutur dan lawan tutur memiliki pranggapan atau asumsi yang sama mengenai apa yang mereka bicarakan. Kesamaan asumsi dapat dipengaruhi oleh konteks luar bahasa, seperti latar belakang budaya, sosial, usia, dan lainya. Hal tersebut melatarbelakangi peneliti judul Analisis Praanggapan Pada Channel Youtobe Podcast Deddy Corbuzier Bersama Novel Baswedan. Masalah dalam penelitian ini ialahbagaimana jenis praanggapan yang terdapat dalam podcast Deddy Corbuzier bersama Novel Baswedan. Penelitian ini bertujuan untuk mengidentifikasi dan mendeskripsikan jenis praanggapan yang terdapat dalam podcast Deddy Corbuzier bersama Novel Baswedan. Pendekatan yang digunakan dalam penelitian ini merupakan pendekatan kualitatif dengan menggunakan metode analisis isi. Teknik pengumpulan data yang peneliti gunakan dalam penelitian ini adalah teknik dokumentasi, teknik simak, dan teknik catat. Hasil penelitian ini menunjukan bahwa, terdapat 66 tuturan yang mengandung praanggapan dalam percakapan amtara Deddy Corbuzier dan Novel Baswedan. Dari 66 tuturan tersebut kemudian dikelompokan menurut jenis praanggapa sesuai dengan teori yang dikemukakan oleh Yule. Ditemukan 16 tuturan yang tergolong dalam jenis praanggapan eksistensial, 9 praanggapan leksikal, 25 praanggapan struktural, 6 praanggapan faktif, 9 praanggapan non faktif, dan 1 praanggapan konterfaktual. Praanggapan struktural paling banyak dijumpai karena objek penelitian berupa tuturan dalam podcast yang bersifat mencari informasi dan mengklasifikasi suatu hal dengan mengajukan pertanyaan.
\end{abstract}

Kata kunci: Pragmatik, Praanggapan, Podcast

\section{Pendahuluan}

Pragmatik merupakan salah satu cabang ilmu lingusitik yang mempelajari bahasa secara eksternal. Dalam kajian ilmu pragmatik terdapat deiksis, tindak tutur, implikatur percakapan, dan praanggapan. Praanggapan dalam ilmu pragmatik dapat diartikan sebagai suatu yang diasumsikan penutur sebagai kejadian sebelum tuturan dihasilkan. Saat berkomunikasi penutur sudah memiliki asumsi atau anggapan berupa suatu informasi dan berharap informasi yang dia sampaikan dapat dimengerti dengan baik oleh lawan tuturnya agar komunikasi mereka dapat berjalan dengan baik. Pernyataan tersebut sejalan dengan pendapat Andini (2018:2) yang mengatakan bahwa suatu komunikasi dapat terjalin dengan baik jika penutur dan lawan tutur memiliki praanggapan atau asumsi yang sama mengenai apa yang mereka bicarakan, jika terdapat perbedaan anggapan maka komunikasi tidak akan berjalan dengan baik. 
Kegiatan berkomunikasi dapat dilakukan kapan saja dan di mana saja dengan adanya bantuan media. Salah satu media komunikasi yang banyak diminati sekarang ialah youtobe. David dkk (2017:3) menyatakan bahwa youtobe merupakan salah satu media sosial yang mulai naik daun sejak 5 tahun yang lalu. Youtobe sudah memiliki lebih dari satu milyar pengguna. Youtobe membuka peluang bagi pengguna internet untuk berbagi video atau membuat konten. Konten yang dibuat dapat dilihat oleh siapa saja. Beragam konten video bisa diuanggah dan diakses dalam youtobe, seperti konten musik, film, gaya hidup, berita, olahraga, gaming, vlog, podcast, dan lainya.

Menurut Fadilah (2017:96) podcast muncul pertama kali sekitar tahun 2005. Awalnya podcast cenderung identik dengan materi audio, namun belakangan podcast dalam bentuk video mulai banyak bermunculan. Podcast terus mengalami perkembangan seiring waktu, kemasanya beragam, dapat berupa drama, monolog, dokumenter, dialog atau talkshow.

Perkembangan konten podcast di Indonesia cukup signifikan. Salah satu konten podcast yang banyak diminati masyarakat Indonesia adalah podcast Deddy Corbuzier. Deddy Corbuzier sering mengangkat tema yang menarik dan aktual. Bintang tamu yang diundang juga berasal dari berbagi macam latar belakang yang berbeda, seperti artis, komedian, politikus, pengusaha, pendakwah, dan lainya. Dalam melakukan wawancara Deddy Corbuzier dapat mengendalikan acara dengan baik, memberikan pertanyaan yang spontan, tidak terikat naskah, dan memberikan pertanyaan-pertanyaan yang kritis namun tetap santai. Hal tersebut melatarbelakangi peneliti memilih judul analisi Analisis Praanggapan Pada Channel Youtobe Podcast Deddy Corbuzier Bersama Novel Baswedan.

\section{Teori}

\section{Pragmatik}

Pragmatik menarik untuk dipelajari karena pragmatik melihat makna bahasa dengan mengaitkan bahasa tersebut dengan konteks luar bahasa. Pragmatik melihat bagaimana penutur dan lawan tutur memahami tuturan masing-masing. Menurut Yule (2006:3) pragmatik merupakan studi tentang makna yang disampaikan oleh penutur dan ditafsirkan oleh mitra tutur. Moris dalam Djajasudarma (2012:71) menyatakan bahwa pragmatik merupakan salah satu cabang ilmu semiotika yang melihat hubungan antara tanda dengan penggunanya. Pragmatik berbeda dengan semantik dan sintaksis yang juga termasuk dalam bidang semiotika. Pragmatik mengkaji makna ujaran dalam kondisi atau situasi tertentu. Dalam Rahardi (2009:20) Leech menyatakan pragmatik merupakan bagian dari pemakaian atau penggunaan tata bahasa tersebut. Lebih lanjut Levinson dalam Dia (2012:1) menyatakan bahwa pragmatik merupakan studi yang mempelajari hubungan bahasa dengan konteksnya. Dengan demikian dapat disimpulkan bahwa pragmatik merupakan studi tentang pemakaian bahasa dengan memperhatikan konteks luar bahasa tersebut agar bahasa dapat dimaknai dengan tepat.

\section{Konteks}

Konteks menjadi komponen yang penting dalam pragmatik. Pragmatik tidak dapat dipisahkan dari konteks karena dalam memahami makna tuturan dalam pragmatik memerlukan konteks. Pentingnya konteks dalam pragmatik ditekankan oleh Mey dalam Nadar (2013:4) yang mengatakan pragmatik merupakan kajian tentang pemakaian 
bahasa manusia yang ditentukan oleh konteks masyarakatnya. Cummings (2007:5) menyatakan bahwa defenisi pragmatik tidak lengkap bila konteksnya tidak disebutkan.

Menurut HP dan Abdullah (2013:145) konteks merupakan situasi atau latar terjadinya suatu komunikasi. Pendapat tersebut sejalan dengan pernyataan Nadar (2013:6) yang mengatakan konteks sebagai suatu hal yang terkait dengan lingkungan fisik dan sosial suatu tuturan ataupun latar belakang pengetahuan yang sama dari penutur dan lawan tutur yang dapat membantu memahami makna tuturan. Menurut Darma (2014:65) konteks merupakan benda atau hal yang mengikuti teks dan menjadi lingkungan atau situasi pemakaian bahasa. Berdasarkan pendapat para pakar di atas maka dapat disimpulkan bahwa konteks merupakan sesuatu yang terkait dengan situasi, lingkungan,latar belakang kesamaan pemahaman penutur dan lawan tutur yang dapat mempengaruhi makna suatu bahasa.

\section{Praanggapan}

Praanggapan atau presuposisi berasal dari kata to pre-suppose, dalam bahasa Inggris memiliki arti to suppose beforehand (menduga sebelumya) yang bermaksud bahwa sebelum berbicara pembicara atau penutur sudah memiliki dugaan tentang apa yang dibicarakanya. Menurut Cummings (2007:42) praanggapan adalah asumsi-asumsi yang tersirat di dalam suatu tuturan linguistik. Suatu tuturan bisa jadi lebih luas dalam memaparkan suatu makna dari yang terlihat. Kalimat yang singkat dan sederhana belum tentu sederhana juga maknanya, karena suatu tuturan terdapat makna yang tersirat. Praanggapan merupakan suatu yang diasumsikan oleh penutur sebagai suatu kejadian sebelum suatu tuturan dihasilkan Yule (2006:43). Yule mengklasifikasikan praanggapan menjadi enam jenis yang dipaparkan berikut ini.

1. Praanggapan Eksistensial

Praanggapan eksistensial menunjukan bagaimana keberadaan suatu hal. Praanggapan ini tidak hanya terdapat dalam susunan kalimat posesif atau kepemilikan, misalnya "buku saya" yang mempraanggapkan jika 'saya punya buku', tetapi lebih luas dan umum lagi dalam frasa nomina tertentu yang diungkapkan, penutur diasumsikan terlibat dalam enitas-entitas yang disebutkan, dan juga pernyataan yang menjukan keberadaan sesuatu. Praanggapan eksistensial dapat ditandai juga dengan penggunaan "ini" dan "itu".

2. Praanggapan Faktif

Praanggapan faktif merupakan praanggapan yang dianggap sebagai kenyaaan yang diyakini secara langsung kebenarannya. ciri utama dari praanggapan ini ialah adanya kata kerja seperti 'tahu', 'menyadari', 'menyesal', 'sadar' , dan lainya. Dalam praanggapan faktif, kefaktualan suatu tuturan dapat juga terlihat melalui partisipan tutur, konteks situasi, dan pengetahuan yang sama.

3. Praanggapan leksikal

Praanggapan leksikal merupakan pemakaian suatu bentuk dengan makna yang dinyatakan secara konvensional yang ditafsirkan dengan praanggapan bahwa suatu makna yang tidak dinyatakan secara langsung tersebut dapat dipahami. Dalam praanggapan ini terdapat makna yang dinyatakan secara tersirat namun lawan tutur dapat memahami makna dari kalimat yang dinyatakan penutur. Praanggapan leksikal juga dapat diidentifikasi dengan melihat penggunaan kata "tambah", "kadang-kadang", "sebagian", dan lainya.

4. Praanggapan struktural 
Praanggapan struktural merujuk pada struktur kalimat-kalimat tertentu yang telah dianalisis sebagai preposisi secara tetap dan konvensional bahwa bagian struktur tersebut sudah diasumsikan kebenaranya. Praanggapan struktural dinyatakan melalui pertanyaan yang langsung bisa dipahami tanpa melihat lagi kata-kata yang digunakan. Penggunaan struktur terlihat pada kalimat introgatif atau kalimat tanya, seperti apa, mengapa, siapa, di mana, kemana, kapan, dan bagaimana menunjukan praanggapan yang muncul dari tuturan tersebut sebagai masalah.

5. Praanggapan Non-faktif

Praanggapan non-faktif merupakan praanggapan yang diasumsikan tidak benar yang merujuk kepada sesuatu yang tidak sesuai dengan kenyataan atau kebenaran. Praanggapan ini dapat dikatakan sebagai sesuatu yang tidak nyataatau belum terjadi. Praanggapan non-faktif biasanya ditandai dengan kata-kata kerja seperti bermimpi, membayangkan, berharap, berpura-pura, dan lainya.

6. Praanggapan konterfaktual

Praanggapan konterfaktual berarti bahwa apa yang diasumsikan atau dipraangggapkan tidak hanya tidak benar, namun juga merupakan lawan dari benar atau bertolak belakang dengan kenyataan. Praanggapan ini menghasilkan pemahaman yang kontradiktif atau bertolak belakang dari pernyataan atau tuturan yang terjadi.

\section{Metode}

Metode yang digunakan dalam penelitian ini adalah metode analisis isi. Menurut Bungin, (2010:84) metode analisis isi merupakan metode penelitian yang mencakup upaya-upaya dalam mengklasifikasikan lambang-lambang yang digunakan dalam komunikasi, menggunakan kriteria dalam klasifikasi, dan menggunakan teknik analisis tertentu dalam membuat prediksi. Metode ini penulis gunakan untuk menggambarkan praanggapan dalam percakapan pada podcast Deddy Corbuzier bersama Novel Baswedan.

Pendekatan yang peneliti gunakan dalam penelitian ini adalah pendekatan kualitatif. Menurut Syamsuddin dan Damaianti (2009:74) pendekatan kualitatif adalah pendekatan yang memahami suatu fenomena sosial dan prespektif individu yang teliti. Tujuan dari pendekatan ini ialah menggambarkan, mempelajari, dan menjelaskan fenomena tersebut. Pemahaman fenomena tersebut dapat diperoleh dengan cara mendeskripsikan dan mengeksplorasikanya dalam bentuk narasi. Oleh karena itu peneliti menggunakan pendekatan kualitatif untuk melihat fenomena praanggapan dalam dialog antara Deddy Corbuzier dan Novel Baswedan.

Sumber data yang dipakai dalam penelitian ini diperoleh dari aktifitas berbahasa dalam video podcast Deddy Corbuzier bersama Novel Baswedan yang diunggah di youtobe pada tanggal 21 dan 22 November 2019. Data dalam penelitian ini adalah tuturan yang mengandung praanggapan dalam video podcast Deddy Corbuzier bersama Novel Baswedan. Peneliti memilih konten bersama Novel Baswedan sebagai sumber data karena dalam percakapan anatra Deddy dan Novel banyak membahas isu-isu sensitif sehingga dalam percakapan mereka banyak hal atau pernyataan yang tidak diungkapkan secara langsung, sehingga banyak ditemukan tuturan yang mengandung praanggapan.

Teknik pengumpulan data yang peneliti gunakan dalam penelitian ini ialah teknik dokumentasi, teknik simak, teknik catat. Adapun teknik analisi data dalam penelitian terdiri dari beberapa tahap. Pertama menemukan lambang atau simbol. Kegiatan ini 
dilakukan dengan mengkategorisasi data penelitian. Lambang atau simbol dalam hal ini merujuk pada teori atau konsep yang digunakan oleh peneliti yaitu teori jenis praanggapan yang dikemukakan oleh Yule. Kedua, klasifikasi data berdasarkan lambang atau simbol. Peneliti mengklasifikasikan data berupa tuturan berdasarkan teori yang digunakan, dalam hal ini merujuk pada praanggapan eksistensial, praanggapan leksikal, praanggapan faktual, praanggapan nonfaktual, praanggapan struktural, praanggapan konterfaktual. Ketiga, rediksi atau menganalisis data. Data yang telah diklasifikasikan berdasarkan jenis pranggapan kemudian peneliti analisis dan melakukan interpretasi terhadap data yang peneliti temukan.

\section{Hasil}

Hasil penelitian ini menunjukan bahwa praanggapan struktural menjadi praanggapan yang paling banyak muncul dalam channel youtobe podcast Deddy Corbuzier bersama Novel Baswedan, sedangkan praanggapan konterfaktual menjadi praanggapan yang paling sedikit muncul. Hal ini menunjukan bahwa banyak informasi yang ingin digali oleh Deddy dari Novel melalui pengajuan pertanyaan. Posisi Deddy sebagai pemilik acara juga menjadi pemicu praanggapan struktural banyak diujarkan oleh Deddy. Deddy juga banyak mengajak Novel untuk berdiskusi mengenai kehidupanya sebagai anggota KPK ataupun diluar anggota KPK sehingga banyak muncul bentuk pertanyaan dalam pembicaraan mereka. Berikut beberapa ini temuan jenis praanggapan dalam channel youtobe podcast Deddy bersama Novel yang disajikan dalam tabel 1.

Tabel.1: Jenis praanggapan pada channel youtobe podcast Deddy bersama Novel

\begin{tabular}{|c|c|c|c|c|c|c|}
\hline $\begin{array}{c}\text { Jenis } \\
\text { Praanggapan }\end{array}$ & Eksistensial & Leksikal & Struktural & Faktif & Nonfaktif & Konterfaktual \\
\hline $\begin{array}{c}\text { Jumlah } \\
\text { Tuturan }\end{array}$ & 16 & 9 & 25 & 6 & 9 & 1 \\
\hline
\end{tabular}

Peneliti akan menganalisis tuturan Deddy Corbuzier dan Novel Baswedan sesuai dengan teori jenis praanggapan yang dikemukakan oleh Yule. Peneliti memilih dan mengumpulkan data sesuai dengan jenis praanggapan yaitu praanggapan eksistensial, leksikal, struktural, faktif, non faktif, dan konterfaktual yang kemudian dianalisis sebagai berikut ini.

\section{Praanggapan Eksistensial}

Praanggapan struktural menjadi jenis praanggapan yang paling banyak dijumpai dalam tuturan antara Deddy dan Novel. Praanggapan struktural dapat diidentifikasi dengan adanya penggunaan kalimat introgatif. Praanggapan struktural sudah diasumsikan sebagai suatu kebenaran yang dapat dipercaya langsung oleh lawan tutura. Pernyataan tersebut sejalan dengan pendapat Setiawan (2018:3) yang menyatakan bahwa, praanggapan atau tuturan yang diikuti kalimat introgatif atau kalimat tanya dapat menuntun orang percaya dengan informasi yang dibagikan tersebut, bukan sekadar pertanyaan, namun juga sebagai suatu kebenaran. Tuturan yang mengandung praanggapan struktural dapat dipahami sebagai suatu kebenaran karena penggunaan kaliamt tanya yang terstruktur. Pernyataan tersebut sejalan dengan pendapat Nurfalupi, (2018:8) praanggapan struktural dinyatakan lewat tuturan yang strukturnya jelas dan langsung dapat dipahami tanpa melihat pemilihan kata-kata yang digunakan. 
Praanggapan struktural paling banyak ditemukan dalam tuturan yang dilakukan oleh Deddy. Hal ini menunjukan bahwa banyak informasi yang ingin digali oleh Deddy dari Novel melalui pengajuan pertanyaan. Posisi Deddy sebagai pemilik acara juga menjadi penyebab praanggapan struktural banyak diujarkan oleh Deddy, dengan tujuan menggali informasi lebih banyak dan mengonfirmasi isu-isu yang yang ditujukan kepada KPK maupun pribadi Novel Baswedan. Deddy juga banyak mengajak Novel untuk berdiskusi mengenai kehidupanya sebagai anggota KPK ataupun diluar anggota KPK sehingga banyak muncul bentuk pertanyaan dalam pembicaraan mereka. Kemunculan praanggapan struktural juga menunjukan bahwa Deddy dan Novel memiliki asumsi yang sama, karena tuturan yang tergolong dalam praanggapan struktural, langsung bisa dipahami sebagai suatu kebenaran.

Kalimat tanya yang muncul dalam tuturan Deddy bersama Novel berupa: apa, siapa, bagaimana, kapan, kenapa, dan lainya. Dia (2012) menyatakan bahwa setiap kata tanya yang digunakan dalam praanggapan struktural memiliki fungsi tertentu, sepeti kata tanya "Apa" biasanya ditujukan untuk menanyakan atau mendapatkan informasi berupa wujud tertentu. kata "Bagaimana' bertujuan untuk menanyakan mengenai proses atau kronologi tentang sesuatu. "kapan" digunakan untuk mencari informasi yang berkaitan dengan waktu. Tuturan yang mengandung praanggapan eksistensial tersebut akan dianalisis sebagai berikut ini.

\section{a) Data 1}

Konteks: Deddy Corbuzier (DC) membuka acara dengan ciri khasnya, kemudian menyapa Bapak Novel Baswedan. DC mengonfirmasi langsung kepada NB yang sudah lama tidak muncul di publik.

DC : “ Fact number one, beliau ini ga pernah ke studio kecuali pertama kali waktu itu ke Najwa, itupun udah tiga bulan yang lalu, udah itu beliau belum ada lagi dimana-mana yaa?".(1)

NB : :Iya belum"

Berdasarkan analisis data, data (1) tersebut termasuk ke dalam praanggapan eksistensial yang mengidentifikasi adanya keberadaan seseorang. Praanggapan eksistensial dapat ditandai adanya entitas atau sesuatu yang berwujud seperti orang, benda, tempat dan objek lainya yang disebutkan oleh penutur yaitu adanya entitas yang mengisyaratkan keberadaan seseorang yang bernama Najwa. Sesuai dengan teori yang dikemukakan Yule, bahwa praanggapan eksistensial dapat diidentifikasi dari penggunaan kalimat posesif atau kepemilikan dan frasa nomina tertentu. Praanggapan yang muncul dalam tuturan tersebut ialah adanya seseorang bernama Najwa yang memiliki sebuah program Talk Show yang pernah di datangi oleh NB. Dalam tuturan tersebut DC memiliki asumsi bahwa NB sudah lama tidak muncul di publik, asumsi DC tersebut dibenarkan oleh NB dengam memberikan jawaban "iya belum".

\section{b) Data 2}

Konteks : Novel membawakan hadiah berupa baju muslimah yang merupakan produk istrinya yang bermerek Emilda Syari. Novel menyerahkan hadiah tersebut kepada Deddy yang ditujukan untuk pasangan Deddy. 
hadiah buat calonnya mas Deddy" (2)

DC :"Hahaha oke”

Berdasarkan analisis data, data (2) tergolong pada praanggapan eksistensial yang menunjukan keberadaan sesuatu atau seseorang. Tuturan tersebut mengidentifikasi adanya keberadaaan seseorang yaitu istri dari Novel dan juga keberadaan calon Deddy Corbuzier. Pernyataan tersebut dapat diidentifikasi kedalam praanggapan eksistensial dengan melihat adanya entitas atau sesuatu yang berwujud seperti orang, benda, tempat dan objek lainya. Hal tersebut sejalan dengan teori yang dikemukakan oleh Yule, bahwa praanggapan eksistensial dapat diidentifikasi dari penggunaan kalimat posesif atau kepemilikan dan frasa nomina tertentu. praanggapan yang muncul dalam penelitian tersebut ialah NB memiliki seorang istri dan DC memiliki seorang calon istri. Sebelum bertutur, NB sudah memiliki asumsi bahwa DC sudah memiliki calon, asumsi NB tersebut dibenarkan oleh DC dengan memberikan jawaban "Oke" sebagai bentuk persetujuan.

\section{c) Data 3}

Konteks: DC menyampaikan adanya oknum yang mengatakan bahwa kasus penyiraman air keras yang dialami oleh NB merupakai suatu kebohongan atau rekayasa. Salah satu alasanya karena menurut orang tersebut kondisi wajah NB tidak terlihat seperti terkena air keras.

DC : "Selain mata, alasan orang itu kan "kenapa ko mukanya gak kenapa-napa? kan kena air keras harusnya mukanya juga hancur" (9)

NB : "Sebenarnya begini, orang yang terkena air keras akan hancur kalau tidak cepat ditangani"

Berdasarkan analisis data, data (9) tersebut tergolong pada praanggapan eksistensial. Praanggapan eksistensial dapat diidentifikasi dengan adanya penggunaan kata "orang itu" sesuai dengan teori yang dikemukakan oleh Yule yang menyatakan bahwa praanggapan eksistensial itu menunjukan keberadaan seseorang atau sesuatu. Pernyataan tersebut dapat diidentifikasi kedalam praanggapan eksistensial dengan melihat adanya entitas atau sesuatu yang berwujud yaitu "orang itu".

\section{Praanggapan Leksikal}

Praanggapan leksikal ditemukan sebanyak 9 tuturan. Pada percakapan antara Deddy dan Novel cukup banyak menggunakan ungkapan tidak langsung atau penyampaian secara tersirat. Informasi yang ingin disampaikan tidak diungkapkan secara jelas, namun maksud penutur masih dapat dipaahami. Pernyataan tersebut sejalan dengan pernyataan Erni dkk, (2019:67) yang mengatakan bahwa dalam pranggapan leksikal penutur menggunakan pernyataan tertentu, sehingga menyiratkan makna pernyataan lain.

Dalam podcast Deddy dan Novel ditemukan tuturan yang diungkapkan secara tidak langsung dengan menggunakan prinsip analogi. Dalam ungkapan secara tersirat atau prinsip analogi tersebut, Deddy dan Novel dapat memahami pembicaraan satu sama lain. Hal tersebut menunjukan bahwa Deddy dan Novel memiliki latar belakang pemahaman yang sama mengenai apa yang mereka bicarakan. Pernyataan tersebut sejalan dengan pendapat Syafi'i dkk, (2020:42) yang menyatakan bahwa penggunaan prinsip analogi saat bercerita perlu mempertimbangkan latar belakang pemahaman antara penutur dan lawan tutur agar cerita tersebut dapat dipahami dengan baik. 
Praanggapan leksikal dalam tuturan Deddy dan Novel tidak hanya ungkapan tersirat berbentuk analogi. Peneliti menemukan kata keterangan seperti, semakin dan bertambah. Hal tersebut sejalan dengan pendapat Dia, (2012: 63-67) yang menyatakan bahwa praanggapan leksikal dapat juga diidentifikasi lewat kata keterangan seperti tambah, kadang-kadang, semua, sebagian, sedikit, dan lainya. Tuturan yang mengandung praanggapan leksikal tersebut akan dianalisis sebagai berikut ini.

\section{a) Data 4}

Konteks: DC bertanya mengapa NB tetap bertahan menjadi anggota KPK setelah banyak penyerangan yang dialaminya, kenapa NB tidak berhenti saja dan menjalani hidup normal.NB kemudian memberikan jawaban dengan analogi mobil pick up.

NB : : "Kita itu mobil pick up, kita punya pilihan mau bawa muatan atau kosong aja ga bawa muatan, kalau kita bawa muatan resikonya pasti kita ga bisa manuver jalanya lebih pelan, berat dan hal-hal lain lah, lebih sulit disitu dan kalau kita ga bawa apa-apa kita jalan bisa full speed, bisa macam-macam lah lebih enak, nyaman jalanya, tapi yang dapat bayaran nanti yang bawa muatan. Hidup ini sementara baik bayaranya nanti di akhirat maupun di dunia." (12)

DC

$$
\text { : "Gue ngerti tapi gue ga terima hahah" }
$$

Berdasarkan analisis data, tuturan (12) tersebut tergolong pada praanggapan leksikal. Dalam tuturan tersebut terdapat makna yang dinyatakan secara tersirat. Menurut Yule praanggapan leksikal merupakan penyampaian makna yang dinyatakan secara tidak langsung atau tersirat namun dapat dipahami oleh lawan tutur. Pada tuturan tersebut penutur menganalogikan kehidupan seperti mengendarai mobil pick up, saat kita hidup dengan berbuat sesuatu kebaikan kita seperti mobil pick up yang penuh muatan, jalanya akan terasa berat, lama, dan perlu berhati-hati, namun pada akhirnya semua itu akan mendapat bayaran dengan muatan atau bekal yang kita bawa.

\section{b) Data 5}

Konteks: Ada oknum yang melaporkan NB ke polisi atas tuduhan penyebaran berita bohong mengenai penyerangan air keras yang dialami NB.

DC : :Tapikan kalau ini sudah dilaporkan ke polisi ini kayaknya bukan masalah percaya ga percaya lagi kan?" (13)

NB : "iya iya"

DC : "Benerga sih"

Berdasarkan analisis data, tuturan (13) tersebut tergolong pada praanggapan leksikal. Dalam tuturan tersebut terdapat makna yang dinyatakan secara tersirat. Menurut Yule praanggapan leksikal merupakan penyampaian makna yang dinyatakan secara tidak langsung atau tersirat. Pada tuturan tersebut penutur mempraanggapkan bahwa ada maksud lain seseorang tersebut melaporkan kasus Novel ke kepolisian sebagai suatu kebohongan atau settingan.

\section{c) Data 6}

Konteks: Deddy bertanya kepada Novel, kenapa Novel masih berani untuk berbicara atau mengungkapkan kebenaran, padahal sudah mengalami beberapa kali penyerangan dari orang yang tidak dikenal karena sikap beraninya yang mengungkap kasus korupsi. Deddy memperingatkan Novel untuk tetap hati-hati dengan bahasa tidak langsung menggunakan analogi mengendarai mobil perlu menggunakan sabuk pengaman. 
DC : "Saya juga percaya hidup mati di tangan Allah, tapi pakai mobil ada seatbelt" (23)

NB : "Iya itu harus, harus di pakai"

Berdasarkan analisis data, data (23) tersebut tergolong pada terdapat praanggapan leksikal, terlihat pada penggunaan pernyataan tidak langsung oleh Deddy yaitu "pakai mobil ada seatbelt." Pernyataan tersebut bertujuan untuk menyatakan bahwa kita tetap perlu waspada, menggunakan pengaman, dan mendahulukan keselamatan, hal tersebuti merujuk kepada Novel Baswedan yang perlu berhati-hati dan perlu pengamanan terkait dengan begitu banyak penyerangan yang sudah dia alami. Praanggapan leksikal dapat diidentifikasi lewat pernyataan penutur yang disampaikan secara tersirat namun dapat dipahami langsung oleh lawan tutur.

\section{Praanggapan struktural}

Praanggapan leksikal ditemukan sebanyak 9 tuturan. Pada percakapan antara Deddy dan Novel cukup banyak menggunakan ungkapan tidak langsung atau penyampaian secara tersirat. Informasi yang ingin disampaikan tidak diungkapkan secara jelas, namun maksud penutur masih dapat dipaahami. Pernyataan tersebut sejalan dengan pernyataan Erni dkk, (2019:67) yang mengatakan bahwa dalam pranggapan leksikal penutur menggunakan pernyataan tertentu, sehingga menyiratkan makna pernyataan lain.

Dalam podcast Deddy dan Novel ditemukan tuturan yang diungkapkan secara tidak langsung dengan menggunakan prinsip analogi. Dalam ungkapan secara tersirat atau prinsip analogi tersebut, Deddy dan Novel dapat memahami pembicaraan satu sama lain. Hal tersebut menunjukan bahwa Deddy dan Novel memiliki latar belakang pemahaman yang sama mengenai apa yang mereka bicarakan. Pernyataan tersebut sejalan dengan pendapat Syafi'i dkk, (2020:42) yang menyatakan bahwa penggunaan prinsip analogi saat bercerita perlu mempertimbangkan latar belakang pemahaman antara penutur dan lawan tutur agar cerita tersebut dapat dipahami dengan baik.

Praanggapan leksikal dalam tuturan Deddy dan Novel tidak hanya ungkapan tersirat berbentuk analogi. Peneliti menemukan kata keterangan seperti, semakin dan bertambah. Hal tersebut sejalan dengan pendapat Dia, (2012: 63-67) yang menyatakan bahwa praanggapan leksikal dapat juga diidentifikasi lewat kata keterangan seperti tambah, kadang-kadang, semua, sebagian, sedikit, dan lainya. Tuturan yang mengandung praanggapan eksistensial tersebut akan dianalisis sebagai berikut ini.

\section{a) Data 7}

Konteks: DC sedang membicarakan kondisi mata NB yang harus dioperasi kemudian harus dipakaikan hard lens.

DC $\quad$ : "Bang kalau lo udah pakai hard lens kenapa pakai kaca mata lagi?” (5)

NB : "kan untuk pelindung saja"

Berdasarkan analisis data, tuturan (5) tersebut terdapat praanggapan struktural, sesuai teori yang dikemukakan oleh Yule praanggapaan struktural dapat diidentifikasi dengan melihat adanya penggunaan kalimat introgatif. Pada tuturan tersebut menggunakan kata "kenapa" yang bertujuan untuk meminta klarifikasi. Praanggapan yang muncul dalam tuturan tersebut ialah DC berasumsi bahwa hard lens dapat 
membantu penglihatan Novel Baswedan tanpa bantuan kacamata lagi oleh karena itu DC mengajukan pertanyaan "kenapa memakai kaca mata” kepada NB.

\section{b) Data 8}

Konteks: DC sedang membicarakan kondisi mata NB yang harus dioperasi kemudian harus dipakaikan hard lens.

DC : : “Tapi itu udah ga bisa dilepas lagi dong, udah ditanam kan?” (7)

NB : : "ngga di lepas setiap mau tidur"

Berdasarkan analisis data, tuturan (7) tersebut terdapat praanggapan struktural, sesuai teori yang dikemukakan oleh Yule praanggapaan struktural dapat diidentifikasi dengan melihat adanya penggunaan kalimat introgatif. Dalam tuturan tersebut DC berasumsi bahwa Hard Lens yang digunakan oleh NB tidak dapat dilepas lagi, namun asumsi itu di bantah oleh NB dengan memberikan jawaban bahwa Hard Lens trsebut harus dilepas sebelum tidur

\section{c) Data 9}

Konteks :Ada yang mengatakan bahwa kasus penyerangan yang dialami Novel Baswedan hanya rekayasa. Deddy bertanya bagaimana perasaan Novel mengenai kasus penyerangan air keras yang dia alami dikatakan hanya sebuah kebohongan.

DC : "Bagaimana rasannya ni bro?, udah jelas begitu ya dibilang $a h$ bohong tu settingan" (8)

NB : "Gini mas Deddy saya itu, kata mas Deddy tadi sering sekali kena masalah, inilah resiko kalau kita berbuat baik"

Berdasarkan analisis data, data (8) tersebut termasuk kedalam praanggapan struktural. Praanggapan struktural dinyatakan melalui pertanyaan yang langsung bisa dipahami tanpa melihat lagi kata-kata yang digunakan. Praanggapan tersebut dapat diidentifikasi dengan adanya penggunaan kalimat tanya. Kalimat tanya yang digunakan adalah "Bagaimana", dari pernyataan tersebut dapat dipahami bahwa Deddy sudah memiliki pemahaman atau asumsi bahwa ada pihak yang mengaggap penyerangan air keras yang dialami Novel tersebut sebagai kehohongan.

\section{Praanggapan Faktif}

Praanggapan leksikal dapat diidentifikasi dengan melihat adanya penggunaan kata kerja. Pernyataan tersebut sejalan dengan pendapat Sofi dkk, (2021:77) yang menyatakan bahwa, praanggapan faktif dapat muncul saat adanya tuturan yang diikuti oleh kata-kata yang menunjukan sebuah fakta atau diyakini kebenaranya, kata yang menunjukan suatu fakta tersebut ialah kata kerja. Praanggapan yang disertai kata kerja yang ditemukan dalam tuturan Deddy dan Novel diataranya ialah, kata tahu, melihat, mendesak, dan lainya. Kata kerja tersebut mempunyai makna pasti yang menunjukan suatu kenyataan. Pernyataan tersebut didukung oleh pendapat Jati dkk, (2017:198) yang menyatakan bahwa kata-kata yang dapat menyatakan fakta dalam suatu tuturan adalah kata kerja yang memberikan makna yang tepat dari tuturan tersebut. Tuturan yang diikuti kata kerja tersebut dtersebut dianggap sebagai suatu kenyataan, pernyataan tersebut sejalan dengan pendapat Setiawan (2018:6) yang mengatakan bahwa praanggapan faktual merupakan praanggapan yang menunjukan bahwa informasi dalam tuturan tersebut 
adalah fakta. Tuturan yang mengandung praanggapan eksistensial tersebut akan dianalisis sebagai berikut ini.

\section{a) Data 10}

Konteks: NB menceritakan setelah penyerangan air keras yang dialaminya. NB di bawa ke salah satu Rumah Sakit di Singapure untuk mendapatkan perawatan lebih baik.
NB : "Saya tahunya begini, setelah saya sampai di Singapura saya dirawat di Berning Senter pusat luka bakarnya Singapore General Hospital” (12)
DC : "Iya, oke"

Berdasarkan analisis data, tuturan (12) tersebut tergolong pada praanggapan faktif yang dianggap sebagai suatu kebenaran, praanggapan faktif diidentifikasi dengan adanya penggunaan kata "tahu". Yule mengemukakan bahwa praanggapan faktif merupakan praanggapan yang diyakini secara langsung kebenaranya, praanggapan ini ditandai dengan penggunaan kata 'tahu', 'menyadari', 'sadar' dan lainya. Praanggapan yang muncul dalam tuturan tersebut ialah NB pernah dirawat di Rumah Sakit di Singapure.

\section{b) Data 11}

Konteks: Ada oknum yang melaporkan NB ke Polisis dengan tuduhan menyebarkan berita bohong mengenai penyerangan air keras yang dialaminya 2 tahun yang lalu.

NB : "Saya tahu lah ada yang melaporkan ke polisi tapi melaporkanya ini motifnya apa? Jangan-jangan dia ngerjain polisi" (16)

DC : "Ya iya makanya, hahaha"

Berdasarkan analisis data, tuturan (16) tersebut termasuk kedalam praanggapan faktif yang dianggap sebagai suatu kebenaran, praanggapan faktif diidentifikasi dengan adanya penggunaan kata "tahu". Yule mengemukakan bahwa praanggapan faktif merupakan praanggapan yang diyakini secara langsung kebenaranya, praanggapan ini ditandai dengan penggunaan kata 'tahu', 'menyadari', 'sadar' dan lainya. Dalam tuturan tersebut juga ditemukan praanggapan struktural yang ditandai dengan adanya penggunaan kalimat introgatif "apa". Praanggapan yang muncul dalam tuturan tersebut ialah adanya motif tertentu dari oknum yang melaporkan Novel ke polisi.

\section{c) Data 12}

Konteks: NB menceritakan mengenai dirinya sebelum menjadi anggota KPK yang pada saat itu masih menjadi anggota Polisi yang ditugaskan ke suatu wilayah.

: "Saya pernah beberapa kali mengalami ketika saya masih sebagai anggota Polri, saya pernah datang ke beberapa daerah yang wilayah saya tentunya, saya melihat orangorang yang terkait dengan ilegal logging contohnya, mereka mendapatkan efek yang luar biasa, samapai saya berjanji saya akan perangi yang begini, tapi ternyata berbuat begitu musuhnya banyak. Sampai-sampai saya pernah berfikir "saya teruskan ga ya" (31)

Berdasakan analisis data, tuturan (31) juga ditemukan praanggapan faktif. Praanggapan faktif dianggap sebagai suatu kebenaran, praanggapan faktif diidentifikasi dengan adanya penggunaan kata kerja, dalam tuturan (31) ini praanggapanfaktif dapat diidentifikasi lewat penggunaan kata kerja "melihat". Praanggapan yang muncul dalam 
tuturan tersebut ialah banyak masyarakat di daerah-daerah yang mengalami dampak ilegal logging yang dilakukan oleh pihak-pihak tertentu.

\section{Praanggapan Nonfaktif}

Praanggapan nonfaktual dipicu oleh adanya penggunaan kata kerja nonfaktif seperti bermimpi, berharap, membayangkan dan lainya. Kata tersebut digunakan untuk mengambarkan bahwa informasi yang disampaikan itu tidak benar atau belum terjadi. Hal tersebut sejalan dengan pendapat Harahab, (2017:97) yang menyatakan bahwa praanggapan nonfaktif dikaitkan dengan penggunaan kata kerja yang dianggap menyajikan informasi tidak benar. Pernyataan tersebut juga sejalan dengan pendapat Sari dkk, (2018:39) yang mengatakan bahwa praanggapan nonfaktif dapat menghasilkan makna-manka yang diragukan kebenaranya.

Dalam pembicaraanya Novel banyak mengungkapkan harapanya, seperti harapan agar pelaku penyerangan air keras terhadapnya dapat ditangkap dan lainya. Munculnya praanggapan nonfaktif ini menunjukan bahwa dalam pembicaraan yang dilakukan oleh Deddy dan Novel masih banyak hal-hal yang belum terwujud, sehingga muncul ungkapan harapan dalam tuturan mereka. Hal ini sejalan dengan pendapat Setiawati (2017:272) menyatakan bahwa praanggapan nonfaktif dapat diidentifikasi lewat penggunaan katakata seperti: bermimpi, membayangkan, berharap, berpura-pura,dan lainya. Tuturan yang mengandung praanggapan eksistensial tersebut akan dianalisis sebagai berikut ini.

\section{a) Data 13}

Konteks: NB membawakan DC kado berupa baju muslimah dari toko istrinya yang diperuntukan untu calon istri DC.

DC : :Saya berharapnya tadi ada baju kokonya" (3)

NB : "Gang bikin cewe jadi adanya cewe"

Berdasarkan analisis data, tuturan (3) tersebut mengandung praanggapan nonfaktif. Praanggapan non-faktif dapat diidentifikasi dengan melihat adanya penggunaan kata "berharapnya", kata tersebut menunjukan sesuatu yang belum terjadi yang memiliki makna berkeinginan supaya terjadi. Sesuai dengan teori yang dikemukakan Yule bahwa praanggapan non-faktif dapat ditandai dengan penggunaan kata-kata seperti bermimpi, membayangkan, berharap, berpura-pura dan lainya. Praanggapan yang muncul dalam tuturan tersebut ialah toko baju milik NB hanya menjual baju untuk perempuan atau muslimah.

\section{b) Data 14}

Konteks: NB membawakan DC kado berupa baju muslimah dari toko istrinya yang diperuntukan untu calon istri DC.

DC : :Saya harapkan nanti suatu saat ada Novel Baswedan series baju kokonya” (4)

NB : :Hahaha iya"

Berdasarkan analisis data, tuturan (4) tersebut mengandung praanggapan nonfaktif. Praanggapan non-faktif dapat diidentifikasi dengan melihat adanya penggunaan kata "harapkan", kata tersebut menunjukan sesuatu yang belum terjadi yang memiliki makna berkeinginan supaya terjadi. Sesuai dengan teori yang dikemukakan Yule bahwa 
praanggapan non-faktif dapat ditandai dengan penggunaan kata-kata seperti bermimpi, membayangkan, berharap, berpura-pura dan lainya. Praanggapan yang muncul dalam tuturan tersebut ialah toko pakaian Novel belum menjual produk pakaian untuk laki-laki.

\section{c) Data 15}

Konteks: NB menceritakan tindakan yang diberikan terhadap matanya yang terluka atau rusak saat penyerangan air kers oleh oknum tidak dikenal.
NB : "Ketika selaput bergelombang itu dikasih hard lens harapanya bisa menggantikan dan selaputnya bisa lurus, kalau lurus pengeliatanya lebih bagus, kalau hard lens di lepas lebih kabur lagi" (6)
DC : :Lebih kabur lagi"

Berdasarkan analisis data, tuturan (6) tersebut mengandung praanggapan nonfaktif. Praanggapan non-faktif dapat diidentifikasi dengan melihat adanya penggunaan kata "harapanya", kata tersebut menunjukan sesuatu yang tidak terjadi atau sesuatu yangtidak sesuai dengan keinginan. Sesuai dengan teori yang dikemukakan Yule bahwa praanggapan non-faktif dapat ditandai dengan penggunaan kata-kata seperti bermimpi, membayangkan, berharap, berpura-pura dan lainya. Praanggapan yang muncul dalam tuturan tersebut ialah Novel menggunakan hard lens untuk membantu penglihatanya yang rusak.

\section{Praanggapan Konterfaktual}

Praanggapan kontekfaktual menjadi jenis praanggapan yang paling sedikit ditemukan dalam tuturan antara Deddy dengan Novel. Praanggapan konterfaktual dapat diidentifikasi dengan melihat ketidakbenaran bahkan kontradiktif terhadap kenyataan. Hal tersebut sejalan dengan pendapat Siregar dkk, (2020:2) yang menyatakan bahwa praanggapan konterfaktual merupakan praanggapan yang tidak benar terjadi, melainkan kebalikan dari suatu kenyataan atau hanya berupa khayalan dan angan-angan. Praanggapan konterfaktual juga bisa dijumpai dalam kondisi kalimat pertama dan kalimat berikutnya bertolak belakang atau kontradiktif. Pernyataan tersebut sejalan dengan pernyataan Setiawan, (2018:4) yang menyatakan bahwa praanggapan konterfaktual dapat dipicu oleh adanya tuturan yang mengandung "if-clause" yang menghasilkan tuturan yang berlawanan dengan tuturan sebelumnya.

Dalam podcast Deddy bersama Novel terebut hanya ditemukan satu tuturan yang tergolong jenis konterfaktual yaitu, saat Novel bercerita mengenai kondisi saat dia mendapatkan penyerangan air keras oleh orang tidak dikenal. Saat itu Novel mengatakan bahwa peristiwa tersebut sebagai akhir dari hidupnya, pernyataan Novel tersebut cukup berlebihan karena dalam kenyataanya peristiwa tersebut bukan akhir dari hidupnya. Pernyataan tersebut sejalan dengan pernyataan Sofi dkk, (2021:81) yang mengatakan bahwa praanggapan konterfaktual memunculkan makna yang berlebihan dan berlawanan dengan kenyataan.. Tuturan yang mengandung praanggapan konterfaktual tersebut akan dianalisis sebagai berikut ini.

\section{Data 16}

Konteks: NB menceritakan mengenai peristiwa penyerangan air keras yang dialaminya padat tanggal 11 April 2017 lalu. Novel menceritakan apa yang dia rasakan saat diserang menggunakan air keras.

NB : "Saya saat diserang saya rasa saya sudah mati, waktu saya dapat air keras itu 
sedemikian panasnya dan saya merasa gagal napas, saya berpikir saya mati, hari terakhir".

DC : "Masih diberikan kesempatan ya"

Berdasarkan analisis data, tuturan (22) tersebut tergolong pada praanggapan konterfaktual karena di dalam dialog tersebut terdapat pernyataan konterfaktual yaitu pernyataan yang tidak hanya tidak benar namun juga bertolak belakang dari kenyataan. Sesuai dengan teori yang dikemukakan oleh Yule bahwa praanggapan konterfaktual memuat hal yang tidak benar dan bertolak belakang dari kenyataan. Pernyataan tersebut terlihat pada kalimat "Saya rasa saya sudah mati", "Saya berpikir saya mati, ini hari terakhir saya". Novel Baswedan beranggapan bahwa dia akan mati saat mengalami penyerangan tersebut namun kenyataannya beliau masih hidup sampai sekarang.

\section{Simpulan}

Berdasarkan analisis data yang telah dipaparkan di atas, menunjukan bahwa ditemukan 66 tuturan yang mengandung praanggapan dalam percakapan pada Podcast Deddy Corbuzier bersama Novel Baswedan. Dari 66 tuturan tersebut kemudian dikelompokan menurut jenis praanggapa sesuai dengan teori yang dikemukakan oleh Yule. Ditemukan 16 tuturan yang tergolong dalam jenis praanggapan eksistensial, 9 praanggapan leksikal, 25 praanggapan struktural atau sebanyak, 9 praanggapan non faktif, 6 praanggapan faktif, dan 1 praanggapan konterfaktual. Dari semua jenis praanggapan yang dikemukaakan oleh Yule dapat ditemukan dalam podcast Deddy Corbuzier Bersama Novel Baswedan.

Praanggapan yang paling banyak dijumapai dalam podcast Deddy Corbuzier Bersama Novel Baswedan adalah praanggapan struktural, yaitu sebanyak 25 tuturan.praanggapan struktural banyak muncul dalam tuturan Deddy, dalam podcast tersebut Deddy banyk mengajukan pertanyaan kedapa Novel untuk menggali banyaak informasi dan mengomfirmasi isu-isu yang terkait dengan Novel. Praanggapan struktural ini juga menuntut lawan bicaranya memnenarkan informasi yang dituturkan. Praanggapan yang paling sedikit ditemukan ialah praanggapan konterfaktual. Hanya ada satu praanggapan konterfaktual yang ditemukan dalam tuturan Deddy dengan Novel.

\section{Ucapan Terima Kasih}

\section{Daftar Pustaka}

Andini, M. D. (2018). Praanggapan Pragmatik Dalam Memoar "Kamu Indonesia Banget Kalau..." Karya Berit Renser [Universitas Negeri Jakarta]. http://repository.unj.ac.id/1273/1/Skripsi Marini Dewi Andini.pdf

AR, S., \& Damaianti, V. s. (2009). Metode Penelitian Pendidikan Bahasa. PT REMAJA ROSDAKARYA.

Bungin, B. (2010). Analisis Data Penelitian Kualitatif.

Chaer, A., \& Agustina, L. (n.d.). Sosiolinguistik (Edisi Revi). Rineka Cipta.

Cummings, L. (2007). Pragmatik (sebuah perspektif Multidisipliner) (A. S. Ibrahim (ed.)). Pustaka Pelajar. 
Darma, Y. A. (2014). Analisis Wacana Kritis dalam Multiperspektif (R. Novitasari (ed.); cetakan ke). PT Refika Aditama.

David, E. R., Sondakh, M., \& Harilama, S. (2017). Pengaruh Konten Vlog dalam Youtube terhadap Pembentukan Sikap Mahasiswa Ilmu Komunikasi Fakultas Ilmu Sosial dan Politik Universitas Sam Ratulangi. E-Journal "Acta Diurna," volume VI. https://media.neliti.com/media/publications/93363-ID-pengaruh-konten-vlogdalam-youtube-terha.pdf

Depdiknas. (2012). kamus Besar Bahasa Indonesia Pusat Bahasa (Edisi Keem). PT Gramedia.

Dia, E. E. (2012). Analisis Praanggapan. Madani (Kelompok Penerbit Intrans).

Djajasudarma, F. (2012). Wacana dan Pragmatik (R. Novitasari (ed.)). PT Refika Aditama.

Erni, Herwandi, \& Sari, I. (2019). Praanggapan dalam Tuturan Dialog Bahasa Persidangan di Pengadilan Negeri Kelas 1A Pekanbaru. GERAM (Gerakan Aktif Menulis), Volume 7 N. https://doi.org/https://doi.org/10.25299/geram.2019.vol7(2).3911

Fadilah, E. dkk. (2017). Podcast sebagai Alternatif Distribusi Konten Audio. Kajian Jurnalisme, $\quad$ Vol. $\quad 1 \quad$ No. $\quad$ http://jurnal.unpad.ac.id/kajianjurnalisme/article/download/10562/6395

Fatmawati, A., Arifianti, I., \& Dewi, D. P. (2020). Praanggapan Eksistensial Teori Ika Valensia Pada Tuturan Penyidik Polri Dalam Interogasi dan Implikasinya Dalam Pembelajaran Debat Kelas X di SMA. Konferensi Ilmiah Pendidikan Universitas Pekalongan.

Gunawan, I. (2013). Metode Penelitian Kualitatif: Teori dan Praktik. Bumi Aksara.

Harahab, J. H. (2017). An Analysis Of Pragmatic Presuppositions In The Editorial Texts [Universitas Sumatera

Utara]. http://repositori.usu.ac.id/bitstream/handle/123456789/19440/157052001.pdf? sequence $=1 \&$ isAllowed $=\mathrm{y}$

HP, A., \& Abdullah, A. (2013). Linguistik Umum. Penerbit Erlanggga.

Jati, E. P., Sumarlam, \& Djatimika. (2017). Presuposisi dan implikatur Dalam Acara Talkshow Indonesia Lawak Klub. International Seminar on Language Maintenance and Shift (LAMAS) 7. http://eprints.undip.ac.id/57990/

Karim, Maknun, T., \& Abbas, A. (2019). Praanggapan dalam Pamflet Sosialisasi Pelaestarian Lingkungan di Wakatobi. Jurnal Ilmu Budaya, Volume 7,. https://doi.org/https://doi.org/10.26499/ttbng.v7i2.146

Kridalaksana, H. (2008). Kamus linguistik (Edisi Keem). Gramedia Pustaka Utama.

Nadar, F. . (2013). Pragmatik dan Penelitian Pragmatik. Graha Ilmu.

Nurfalupi, R. (2018). Praanggapan dalam Komik Strip Anak Indonesia Mentari Edisi 291, 306, 327, 398, 443, 514, 525, 574, 577, 596, 602, 606 dan 607. In Artikel Skripsi. Universitas Nusantara PGRI Kediri. 
Rahardi, K. (2009). Sosiopragmatik (W. Hardani (ed.)). PT Gelora Aksara Pratama.

Sari, L. ika, Retnowaty, \& Musdolifah, A. (2018). Presuposisi Pada Bahasa Spanduk Iklan Warung Bakso Di Balikpapan. BASA TAKA, Volume 1,. https://media.neliti.com/media/publications/286720-presuposisi-pada-bahasaspanduk-iklan-wa-0d342076.pdf

Setiawan, D. (2018). Presuposisi dalam Percakapan Antar Tokoh Novel Kembang Turi Karya Budi Sardjono [Universitas Tanjungpura]. https://jurnal.untan.ac.id/index.php/jpdpb/article/download/28936/756765786 85

Setiawati, S. (2017). Analisis Praanggapan dalam Novel Negeri Diujung Tanduk dan Pemanfaatanya Sebagai Bahan dan Kegiatan Menulis Teks Eksposisi. Jurnal Penelitian Pendidikan, Volume 17,. https://doi.org/https://doi.org/10.17509/jpp.v17i3.9621

Siregar, T., Hariadi, J., Effendi, D. I., \& Z, S. (2020). Analisis Presuposisi Pada Percakapan Siswakelas Xi Jurusan Tata Busana Smk Negeri 3 Langsa Tahun 2019. Jurnal Samudra Bahasa, Volume 3 N. https://doi.org/https://doi.org/10.33059/jsb.v3i1.2203

Sofi, M. S., Iye, R., Karim, Tenriyawali, A. Y., \& Susiati. (2021). Ideologi Pranggapan Pamflet Sosialisasi Pelestarian Lingkungan Di Kabupaten Buru. BAHTERA, Volume 20. https://doi.org/https://doi.org/10.21009/bahtera.201.07

Sugiyono. (2015). Metode Penelitian Pendidikan: Pendekatan Kuantitatif, Kualitatif dan $R \& D$. Alfabeta.

Syafi'i, B. A., Febriana, N. C., \& Wulandari, R. A. (2020). Konteks dan Inferensi Film Dilan 1991 Karya Pidi Baiq. Hasta Wiyata, $V \quad o \quad l \quad l \quad 3$. https://doi.org/10.21776/ub.hastawiyata.2020.003.02.04

Yule, G. (2006). Pagmatik. Pustaka Pelajar. 